\title{
Aspectos do Conto Mínimo e da Cena Teatral em Fernando Bonassi
}

\author{
Letícia Mendes de Oliveira
}

Resumo

\begin{abstract}
Este ensaio examina o conceito de conto mínimo através da análise de três obras do escritor Fernando Bonassi: 100 histórias colhidas na rua, 100 coisas e Passaporte. Através do cotejamento entre as linguagens literária e teatral, formulamos uma relação entre conto e cena.
\end{abstract}

Palavras-chave: Fernando Bonassi. Conto mínimo. Literatura contemporânea.

É nesse instante. Brotando do meio dos homens. Uma faca anônima espetada na sua direção. Um arco. Música. Percebe o lance inacabado, mira a lâmina e se projeta.

Fernando Bonassi, conto 17, 100 histórias colhidas na rua.

Fernando Bonassi é ficcionista, dramaturgo e roteirista. Destacando-se no cenário literário brasileiro, a partir da década de 90, Bonassi conta com uma obra de ficção de mais de vinte livros publicados. Este autor mantém atividades artísticas variadas: elabora roteiros de cinema, escreve para o jornal Folha de São Paulo ${ }^{1}$ uma coluna quinzenal no Caderno Ilustrada e esteve relacionado à chamada "Geração 90" (este termo surgiu a partir publicação do livro Geração de 90: manuscrito de computador, de Nelson de Oliveira, em 2001). À primeira vista, a ficção de Bonassi se conecta ao realismo urbano e violento dos anos 60 e 70 no Brasil, pois retrata homens e mulheres situados em meio a paisagens urbanas decadentes e conflituosas. Porém, sua ficção ultrapassa o caráter de puramente retratar ou denunciar uma realidade social. A narrativa investe nas tensões entre a reflexão ética das histórias e a exposição de uma linguagem fragmentária, característica da cultura contemporânea. Ressaltamos ainda a leitura de dois romances que deflagraram a forma de um realismo brutal, linguagem característica do escritor: Um céu de estrelas, de 1991, e Subúrbio, de 1994. Ambos enfocam personagens que não são nomeados, vivendo em universos de degradação física e psicológica, causada pela miséria da periferia da cidade.

Dentre os gêneros literários que utiliza, da poesia passando ao romance e chegando à literatura infanto-juvenil, a microficção possui um lugar significativo. Neste sentido, Fernando Bonassi é um escritor de poucas palavras. No entanto, o que parece "pouco" pode enganar o leitor à primeira vista. Lugar que suscita múltiplos sentidos. Os contos mínimos de Fernando Bonassi representam um "mundo em miniatura". "A 
miniatura é uma das moradas da grandeza" (BACHELARD, 1989, p. 164), diz Gaston Bachelard. As coisas diminutas e insignificantes, consideradas à primeira vista desprezíveis, trazem, em seu bojo, a grandiosidade dos acontecimentos, a lucidez sobre a vida ou a crueldade do mundo. Do diminuto para a amplidão, a escrita de Bonassi é mínima, porque a síntese atravessa grande parte da sua literatura. Deste modo, buscando investigar o conto mínimo, analisamos três obras: 100 histórias colhidas na rua (1996), 100 coisas (2000) e Passaporte (2001). Do último livro citado, citamos um conto:

essas rodoviárias...

...e esses homens desesperados por um cartão de ponto e essas mulheres muito fiéis de cabeça coberta de panos encardidos e essas crianças boquiabertas de monóxido de carbono e esses ovos fósseis de desejo e esses pastéis lubrificados de baixa potência e essa pressa intransferível e essas Coca-colas ardidas na garganta e essa certeza duvidosa de novos tempos e esse fracasso de barbas rala e branca e esses enormes hematomas invisíveis e essas malas frágeis de memória arremessadas em gigantescos porta-malas fazendo um eco ensurdecedor que ninguém vai ouvir... (BONASSI, 2001, conto 135)

"essas rodoviárias" expõe seres, objetos e ações que se misturam, instaurando um sentimento de desorientação e mal-estar. Há uma constante sobreposição de imagens, através da simultaneidade de ações. Há também a insegurança quanto ao futuro - "certeza duvidosa de novos tempos" - e a sensação de incapacidade quanto ao presente - "fracasso de barbas rala e branca". A "pressa de se chegar a algum lugar" é a mola propulsora das ações. Um movimento ininterrupto de imagens, auxiliado pela presença veemente da vírgula, que configura a sensação de uma "rapidez inútil". O universo da rodoviária é intragável, sufocante e impessoal (notemos as palavras "ardidas", "fósseis" e "monóxido de carbono", "intransferível", como alguns dos exemplos que conotam essa idéia).

Apesar de um universo incógnito, as palavras "esse" e "essa" trazem a noção de que o espaço mostrado torna-se uma paisagem muito revisitada pela população urbana. Isso porque percorremos "esse" cotidiano todos os dias, quando saímos de casa, ou quando vemos essas imagens através de notícias televisivas ou impressas. A sensação de que tudo foi visto traz outro sentimento, próximo do desencantamento: o tédio. Local de passagem, a rodoviária torna-se um lugar com fronteiras físicas e virtuais, entre a origem e a travessia do sujeito contemporâneo. A imagem poética causada pela frase final - "ecos sendo arremessados em gigantescos porta-malas que ninguém vai ouvir" - traduz, através da contraposição entre as expressões "eco ensurdecedor" e "ninguém vai ouvir", o silêncio insuportável produzido, paradoxalmente, por um lugar repleto de poluição sonora. O som das malas sendo jogadas expressa incomunicabilidade, alienação e solidão. Temas que revelam um olhar crítico e poético sobre a realidade contemporânea. De acordo com esta idéia os temas da ficção de Fernando Bonassi dialogam com algumas tendências da ficção contemporânea, tais como a miséria e a violência brasileira, aliadas ao contexto dos efeitos da globalização e da informatização.

Uma das tendências da ficção contemporânea refere-se ao gênero do conto mínimo, que apresenta o limite de sua extensão: uma página ou apenas algumas linhas (como no conto-frase de Bonassi, presente em 100 histórias colhidas na rua: "Filho que nasce torto pede esmola"). Flora Süssekind (SÜSSEKIND, 2000, p. 4-11) ressalta a redução como uma tendência recorrente na narrativa, tanto no sentido da retomada de gêneros, como a novela, quanto no advento do conto mínimo, segundo suas palavras. Baseados na afirmativa de Süssekind, preferimos o uso da expressão 
conto mínimo à forma tradicionalmente usada de mini-conto, visto que a palavra mínimo possui o sentido de 'a menor parte de qualquer objeto', por isso, suficiente e necessária para que tal objeto exista. O conto mínimo não é o "resumo" do conto tradicional, mas um gênero singular, que utiliza a síntese como uma escolha estética de composição da narrativa. Deste modo, consideramos, contrário a um sentido restrito de "redução do texto", a idéia de complexidade, concentração das histórias e estrutura específica do gênero que é recente no panorama da narrativa contemporânea. Pautado pelo pensamento de que todo conto é composto dentro de limites (limite de espaço e de tempo ficcionais, limite de ação na história, limite de personagens, limite de páginas, limite de duração da leitura), acreditamos que o gênero apresenta uma singularidade: a concentração de recursos narrativos.

É possível realizar também, a partir da leitura dos contos de Bonassi, uma interlocução semiótica que possa aproximar teatro e narrativa literária, em virtude da experiência que o autor tem com tais expressões artísticas. Além da sua atuação literária, o escritor transita em duas áreas: o teatro e o cinema. Formado em roteiro de cinema pela Universidade de São Paulo, Bonassi roteirizou os filmes: Os matadores (1997), direção de Beto Brant e colaboração de Marçal Aquino e Victor Navas; Sonhos tropicais (2000), direção de André Sturm; e Carandiru (2003), direção de Hector Babenco, em parceria com Victor Navas, baseado no livro Estação Carandiru, de Drauzio Varella.

Quanto à linguagem teatral, Bonassi vem realizando diversas dramaturgias e adaptações para grupos e profissionais da área. Uma montagem deve ser destacada: a dramaturgia do espetáculo Apocalipse 1.11 (São Paulo, 2000), composta em colaboração com os atores do grupo de teatro Vertigem e com a direção do pesquisador e professor da Universidade de São Paulo, Antônio Araújo. Este foi o terceiro espetáculo que pertenceu à Trilogia Bíblica, sendo que os dois primeiros são intitulados respectivamente: Paraíso perdido, de 1992, e Livro de Jó, de 1995 . O processo visou integrar o trabalho dos atores, do diretor e do dramaturgo para uma composição coletiva da obra teatral. A proposta abrangeu também a utilização de espaços alternativos de atuação, incitando no espectador uma sensação de participação: a peça Paraíso perdido foi realizada em um igreja, O livro de Jó em um hospital e Apocalipse 1,11 em um presídio. Cada espaço representava um universo social distinto que era relacionado aos temas das passagens bíblicas selecionadas.

A primeira interseção entre literatura e teatro refere-se à ficção como um aspecto comum às duas linguagens, pois ambas se constituem como artes representativas, nas quais observei elementos comuns, tais como a ação de um personagem situado em um determinado tempo e espaço. Entretanto, o teatro se apresenta como uma expressão de realização efêmera, pois seu desenvolvimento temporal é transitório, exigindo a presença física de atores, em um único período corrente e que nunca se repete da mesma forma. No teatro, a imaginação toma forma concreta, através de um evento ao vivo, no qual os personagens representam seu drama diretamente para os espectadores, sem a interferência de um interlocutor. O modo de enunciação inclusive é uma diferença marcante em relação à narrativa literária. No texto de ficção, apreendemos as mesmas imagens compostas pela trama da narrativa, através da leitura e das construções sintáticas que instauram histórias imaginárias.

Atento ao diálogo com a linguagem teatral e levando esta experiência para sua literatura, os contos mínimos apresentam traços dessa expressão artística. A microficção tende a eliminar uma visão onisciente do narrador sobre a ação, bordejando os próprios limites do gênero. O narrador de Bonassi deseja lançar-se no 
universo ilusório em que personagens e situações se oferecem sem intermediários ao seu receptor, do mesmo modo como acontece no teatro.

Quando lemos os contos de Bonassi, percebemos alguns recursos narrativos que tendem a romper com essa distinção demarcada entre representação e narração, tais como: a rapidez da narração, a descrição sucinta do personagem, a concentração da ação e do conflito, a velocidade no desenvolvimento da história, a mudança repentina de uma ação para outra e os desfechos inesperados, que fazem com que a leitura das histórias traga a impressão de que o "leitor esteja assistindo a uma cena teatral". Ao ler, acreditamos que o leitor pode visualizar encenações imaginárias e futuras representações. Uma página de um livro também é um palco de teatro. Nela se encenam paixões, tragédias, comédias e dramas. Ao lermos uma história, vivenciamos as experiências dos personagens e nos identificamos com seus conflitos. Assim como encontramos um jogo de interação entre encenação e platéia, o mesmo processo pode ser verificado entre texto narrativo e leitor. É como se o texto escrito pudesse, mesmo que de modo fugaz, alcançar a categoria de cena. Nesse quadro, a literatura não perde suas especificidades enquanto palavra. O que discuto é a presença de elementos da enunciação teatral em um texto literário, que não sejam necessariamente aqueles destinados à encenação. Este é o espetáculo que proponho: a reflexão que contempla a presença do teatro na literatura. Uma escrita espetacular.

$\mathrm{Da}$ aproximação entre narrativa literária e teatro, podemos destacar especificamente a estrutura narrativa da cena e do conto. A cena apresenta a idéia de fragmento ou episódio que integra o todo de um espetáculo. Porém, apesar de integrar-se a uma encenação maior, a estrutura da cena apresenta uma lógica interna e independente ao todo. Durante uma cena, a concisão da ação relaciona-se à instauração de um conflito entre personagens. A cena expõe imagens e situações fragmentadas e sobrepostas, gerando lacunas no entendimento do espectador. Porém, da mesma forma que o conto, uma vez dado o ponto de partida, a cena pode desencadear outras ações, funcionando como "pequenos núcleos do espetáculo" ou, assim como o conto, um espetáculo mínimo. A noção de acontecimento, própria do conto, pode ser relacionada à realização do teatro, porque ambos apresentam o efeito de presente imediato.

Além da presença da cena, o conto mínimo apresenta um diálogo com o texto teatral. Escrito com o objetivo de ser encenado, 0 texto de teatro apresenta geralmente dois tipos de discurso: o diálogo e a rubrica. Evidenciamos o papel da rubrica, pois ela é semelhante ao conto mínimo, ou seja, relata ações, descreve personagens, situando-os em determinado contexto espacial e temporal e registra as mudanças de um acontecimento para o outro. Porém, mesmo denotando um sentido completo enquanto leitura, as rubricas destinam-se a serem encenadas. A rubrica aproxima-se do conto mínimo através de um diálogo textual e narrativo, pois, em ambas as linguagens, é possível encontrarmos a presença de tais elementos de composição.

Curta e concentrada, a microficção apresenta situações dramáticas intensas, tragédias cotidianas, sátiras do homem contemporâneo e o retrato cênico dos territórios e dos espaços. Investigando a narrativa dos contos mínimos, identificamos em cada livro de Bonassi algumas singularidades, que se relacionam à cena de teatro, sejam elas temáticas ou estéticas.

No livro 100 histórias, os contos apresentam personagens sem nomes, encarnando tipos comuns. Os problemas são concretos, objetivos e não subjetivos, pois apresentam o confronto explícito entre duas forças. São seres anônimos que 
buscam uma saída para a própria sobrevivência, dramatizando suas histórias. Personagens que assumem categorias sociais diversas em situações conflituosas iminentes: o pai que abusa da filha, a prostituta e o bandido, a mãe e o filho desaparecido, o psicótico e o travesti, rebeliões contra a polícia.

Em 100 coisas, Bonassi apresenta um personagem subjetivo, que questiona sua própria existência. Porém, o sujeito retratado é descentrado de razão, psicologia e emoção. No lugar de tais aspectos, a ilógica e a ironia regem sua trajetória. Por isso, temos uma narrativa entrecortada por temas trágicos e, ao mesmo tempo, banais. São seres patéticos que zombam de um mundo decadente: o tédio da sala de estar defronte à televisão, o sufoco dentro de um ônibus lotado e o nervosismo de se pagar uma conta em uma fila de banco.

Passaporte é a obra de Fernando Bonassi em que percebemos o abandono da história como fio condutor da narrativa; a presença da figura humana é descartada em detrimento da potencialidade dos espaços físicos. É evidente que tais espaços se referem aos seres que ali habitam, pois a partir da visualização dos lugares é possível se caracterizar determinados sujeitos. Confirmo a idéia de que o personagem não é um elemento central da narrativa, isto porque a própria noção de personagem se modificou. Passaporte possibilita ainda um importante diálogo com o teatro contemporâneo: visualizar as imagens contidas do texto como se fossem um espetáculo sonoro, verbal e plástico, e que não veiculam necessariamente uma história linear. São corpos humanos e inumanos lançados em espaços múltiplos: cercas elétricas de uma cidade violenta, malas arremessadas em imensos porta-malas, bêbados estirados em meios-fios e chupetas esquecidas nos berços.

Ao experimentar idéias e hipóteses, procuramos lançar um duplo olhar sobre a ficção de Fernando Bonassi: vislumbrar encenações imaginárias no conto mínimo e fecundar a análise sobre a obra do autor. Aproximando-nos do fim do nosso texto, narramos, finalmente, um que impulsionou a reflexão sobre cena e conto, e que está presente em 100 histórias colhidas na rua.

No centro do vale - para além dos fios de luz da estrada e da parede de montanhas -, onde o véu de chuva e neblina une o céu à terra, um homem transformou a vagina de sua mulher numa máscara e a está sugando. Essa mulher mergulhada, girando no eixo da coluna, masca o lábio superior. Nenhuma palavra. (BONASSI, 1996, conto 28, p. 63)

Como uma rubrica poética, repleta de imagens e percepções, dois seres se amam em um lugar longínquo, incógnito - no "centro do vale". Um ato emoldurado pelo olhar fortuito do narrador: o mergulho de uma mulher apreendido no momento exato em que o leitor visualiza a ação. A cena fugaz e instantânea nos mostra que o conto mínimo ultrapassa a dureza do cotidiano e transborda a beleza e o inesgotável da vida. O sublime das coisas ínfimas e minúsculas. O êxtase da contemplação. O silêncio da cena. E o desejo de não se dizer mais nada, quando a imagem sufoca as explicações desnecessárias.

Neste breve momento, é possível se captar um efeito teatral, que incita os sentidos do receptor para além do transitório dos acontecimentos. Dizemos que, paradoxalmente, o teatro imprime sua permanência justamente a partir do efêmero de sua condição. O teatro é um exercício estético do inacabado, um processo em permanente construção, que pretende apresentar mundos e sujeitos que também se transformam a todo instante. Inacabados, cena e conto são partes mínimas de histórias mais amplas e, ao mesmo tempo, plenas de sentido.

Acreditamos assim que toda cena, todo conto é um grande improviso. Almejando um caráter instantâneo, o conto mínimo aproxima-se do teatro, mesmo sabendo que 
não passa de uma inscrição no papel. Através das palavras que fluem para além do limite da página, o conto mínimo desafia o transitório e permanece em nossa memória, estimulando leituras que instauram um espetáculo imaginário. Para se enxergar o pequeno, é preciso ter olhos grandes, olhos vivos para se captar o lance inacabado.

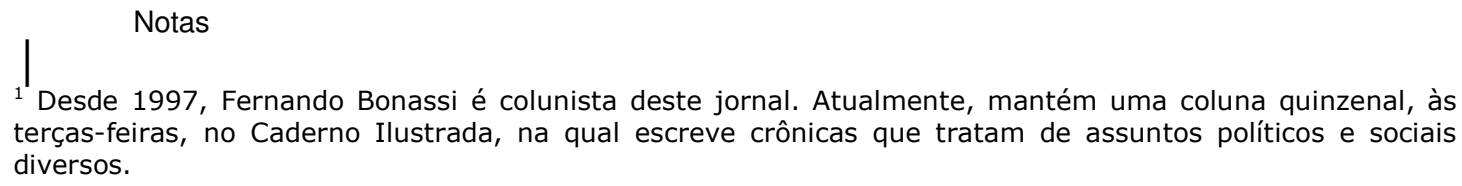

Abstract

This essay examines the concept of minimal tale by means of analysing three tales written by Fernando Bonassi: 100 histórias colhidas na rua, 100 coisas and Passaporte. A relation between tale and theatre is established by the comparison between the literary and theatrical languages.

Key words: Fernando Bonassi. Mininal tale. Contemporary literature.

\section{Referências}

BACHELARD, Gaston. A poética do espaço. Tradução de Antônio de Pádua Danesi. São Paulo: Martins Fontes, 1989.

BONASSI, Fernando. 100 histórias colhidas na rua. São Paulo: Scritta, 1996.

BONASSI, Fernando. 100 coisas. São Paulo: Angra, 2000.

BONASSI, Fernando. Apocalipse 1,11 - o Processo Texto. In: NESTROVSKI, Arthur (Ed.). Teatro da Vertigem. Trilogia bíblica. São Paulo: Publifolha, 2002. p. 61-64.

BONASSI, Fernando. Passaporte (relatos de viagens). São Paulo: Cosac \& Naify Ed., 2001.

BONASSI, Fernando. Subúrbio. São Paulo: Scritta, 1994.

BONASSI, Fernando. Um céu de estrelas. São Paulo: Siciliano, 1991.

BONASSI, Fernando. Violência e paixão. In: OLIVEIRA, Nelson de (Org.). Geração 90: manuscritos de computador. São Paulo: Boitempo Editorial, 2001. p. 41-51.

LYOTARD, Jean-François. A condição pós-moderna. Tradução de Ricardo Corrêa Barbosa. 7.ed. Rio de Janeiro: José Olympio, 2002.

SÜSSEKIND, Flora. Escalas e ventríloquos. Folha de São Paulo, Caderno Mais, São Paulo, p. 4-11, 23 jul. 2000. 